\title{
Validating the Persian Version of Reflective Thinking Questionnaire and Probing Iranian University Students' Reflective Thinking and Academic Achievement
}

\author{
Afsaneh Ghanizadeh \\ Imam Reza International University, Mashhad, Iran, a.ghanizadeh@imamreza.ac.ir \\ Safoura Jahedizadeh \\ Ferdowsi University of Mashhad, Iran, jahedi.s1310@gmail.com
}

Scholars in higher education deem reflective thinking as integral to the development of professional disciplinary practices. One of the major issues in studying reflective thinking pivots around its conceptualization and assessment. Over the years, researchers have used several methods and scales to measure reflective thinking. One of the most widely known scales of reflective thinking was constructed and validated by Kember et al. (2000). It is entitled 'Reflective Thinking Questionnaire (RTQ)' and includes 16 items measuring four types of reflective thinking: understanding (UND); reflection (REF); critical reflection (CREF); habitual action (HA). The present study aimed at validating the Persian version of RTQ among one hundred ninety six English as a foreign language (EFL) university students. It then scrutinized the role of reflective thinking in academic achievements measured by grade point average (GPA). The association of learners' reflective thinking style with their educational level and gender was also estimated. To conduct the research, the scale was first translated into Persian and its validity (computed via confirmatory factor analysis, convergent, and divergent validity estimates) and reliability (computed via Cronbach's alpha) were substantiated. It was indicated that among the comprising factors of reflective thinking, UND received the highest mean followed by REF and CREF.

Keywords: EFL learners, reflective thinking, language achievement, understanding, reflection, critical reflection, habitual action

\section{INTRODUCTION}

Higher education institutions serve three functions, namely education, research, and contribution to society. As proposed by Smith and Szymanski (2013), what underpins all these functions is to equip students for success in life by becoming fully-functioning

Citation: Ghanizadeh, A. \& Jahedizadeh, S. (2017). Validating the Persian Version of Reflective Thinking Questionnaire and Probing Iranian University Students' Reflective Thinking and Academic Achievement. International Journal of Instruction, 10(3), 209-226. https://doi.org/10.12973/iji.2017.10314a 
members of the society. The characteristics of higher education formulated based on interaction, exploration, and problem solving tasks provide the opportunities for learners to enhance their higher order abilities. Due to the wide-ranging functions of higher education, students tend to look beyond the surface of the new subject material and move towards mental reflections, a process known as reflective thinking which is acknowledged to be as one of the key skills towards sustainable development in higher education institutions (Dawe, Jucker, \& Martin, 2005). In effect, researchers in the domain of higher education conceived reflective thinking as integral to the development of professional disciplinary practices (Barton \& Ryan, 2014). It is also contended that in recent years, the notion of reflective thinking is increasingly incorporated to higher educational discourses (Moore, 2011). The term "reflection", or "reflective thinking" is defined as "active, persistent, and careful consideration of any belief or supposed form of knowledge in the light of the grounds that support it and the conclusion to which it tends" (Dewey, 1933, p. 118). In other words, reflective thinking is an active and continuous process of thinking about any subject matter which encourages and guides the learning process and involves a state of perplexity, hesitation, doubt, and mental difficulty as well as an act of inquiring, hunting, and searching to solve the sophisticated issues.

As far as the components of reflection are concerned, Mezirow (1977) introduced the four main constructs of reflective thinking, namely; habitual action, understanding, reflection, and critical reflection. Habitual action is defined as "what has been learnt before and through frequent use that is performed automatically or with little conscious thought. Common examples are using a keyboard or riding a bicycle" (Kember, Leung, Jones, \& Loke, 2000, p. 383). The second component, i.e., understanding is the application of prior knowledge with no thoughtful evaluation. An obvious example is 'book reading' of university students. Commensurate with Bloom's (1979) taxonomy, knowledge, comprehension, application, analysis and synthesis categories would generally be positioned in understanding calibration. The third subscale is reflective learning which is "the process of internally examining and exploring an issue of concern, triggered by an experience, which creates and clarifies meaning in terms of self, and which results in a changed conceptual perspective" (Kember, et al., 2000, p. 384). The last category is critical reflection which involves an awareness of the reasons behind our perceptions, emotions, and actions. This entails realizing that our activities are regulated by our values and beliefs and requires a critical appraisal of our assumptions from conscious and unconscious prior learning and their outcomes.

\section{REVIEW OF LITERATURE}

Studies on reflective thinking have paid primary attention towards reflective thinking among teachers (e.g., Shokouhi, Moghimi, \& Hosseinzadeh, 2015). Only recently students' reflective thinking found its way to research studies. These studies have been mainly concerned with the nexus between student reflective thinking and some other variables such as; learning approaches, self-efficacy, and academic performance, student self-assessment of reflection and teacher-awarded marks (Lim-Ng, 2009), reasoning 
ability, intellectual stimulation, and motivation (Sargent, 2015), critical thinking, selfmonitoring, and academic achievement (Ghanizadeh, 2016).

One of the major snags in studying reflective thinking revolves around its conceptualization and assessment. Over the years, researchers have used several methods and approaches to measure reflective thinking (Kalk, Luik, Taimalu, \& Täht, 2014). In particular, these methods include: qualitative approach (e.g., Maaranen \& Krokfors, 2007) which comprise ethnographic field notes and audio taped discussions (e.g., Ottesen 2007), interviews (e.g., Krebel, 2005; Alger, 2006), posting comments in blogs (e.g., Shoffner 2009), essays (e.g., Maaranen \& Krokfors, 2007), and portfolios (e.g., Tigelaar, Dolmans, De Grave, Wolfhagen, \& Van Der Vleuten, 2006), quantitative approach (e.g., Kember, Leung, Jones, and Loke, 2000; Sobral, 2001; ) and mixedmethod approach (e.g., Killeavy \& Moloney 2010) in which different scales built on diverse approaches and theories have been applied to examine reflective thinking.

One of the most widely known scales of reflective thinking was constructed and validated by Kember et al. (2000). The scale known as' reflective thinking questionnaire (RTQ)' contains four subscales: habitual action, understanding, reflection, and critical reflection. Habitual action is defined as "what has been learnt before and through frequent use that is performed automatically or with little conscious thought. Common examples are using a keyboard or riding a bicycle" (Kember et al. 2000, p. 383). The second component, i.e., understanding is the application of prior knowledge with no thoughtful evaluation. An obvious example is "book reading" of university students. Commensurate with Bloom's (1979) taxonomy, knowledge, comprehension, application, analysis, and synthesis categories would generally be positioned in understanding calibration. The third subscale is reflective learning which is "the process of internally examining and exploring an issue of concern, triggered by an experience, which creates and clarifies meaning in terms of self, and which results in a changed conceptual perspective" (Kember et al. 2000, p. 384). The last category is critical reflection which involves an awareness of the reasons behind our perceptions, emotions, and actions. This entails realizing that our activities are regulated by our values and beliefs and requires a critical appraisal of our assumptions from conscious and unconscious prior learning and their outcomes.

Since the introduction of RTQ, various studies employed the scale to explore different dimensions of learners' reflective thinking (e.g., Phan, 2006; Başol \& Gencel, 2013; Ghanizadeh, 2016). Notwithstanding the high reliability and validity of the original scale (Kember et al, 2000), in studies carried out in different contexts, it is generally recommended that the scale be contextualized and localized in each context to ensure its validity. Efforts to substantiate the validity of RTQ in different countries include: Kalk, Luik, Taimalu, and Täht, (2014) in Estonia among student teachers; Başol and Gencel (2013) in Turkish with science students; Lucas, and Leng Tan, (2006) in England and Wales with accounting and business students.

Despite various studies conducted in relation to the notion of reflective thinking in different contexts and among various disciplines, to the best knowledge of the researchers, no study has attempted to localize the instrument in an Iranian context by 
translating the scale to Persian and then validating the instrument. Consequently, the present study seeks to validate RTQ among Iranian university students majoring in teaching English as a foreign language (TEFL). It then aims at examining the impact of each component of reflective thinking on academic achievement. It also explores the role of students' demographic variables (gender and educational level) in reflective thinking.

To attain the goals of present research, the following research questions were posed:

1) Is the Persian version of RTQ a reliable and valid tool for measuring Iranian students' reflective thinking?

2) What is the profile of Iranian university students' reflective thinking?

3) Is there any relationship between university students' reflective thinking and their academic achievement as measured by their GPA?

4) Does university students' reflective thinking differ with their educational level?

5) Does university students' reflective thinking differ with their gender?

\section{METHOD}

\section{Participants}

One hundred ninety six (196) Iranian university students participated in this study (112 females and 75 males; 9 participants did not specify their gender). Their age varied from 20 to 32 years old $(M=22.5, S D=3.06) ; 15$ participants did not specify their age. They were $\mathrm{BA}$ and MA students $(\mathrm{BA}=101, \mathrm{MA}=95)$ who were studying English Teaching at three universities in Mashhad, a city in Northeast of Iran.

\section{Instrument}

\section{Reflective Thinking Questionnaire (RTQ)}

To assess reflective thinking, the RTQ developed by Kember, Leung, Jones, and Loke (2000) was utilized. It includes 16 items measuring four types of reflective thinking (habitual action, understanding, reflection, and critical reflection). According to Leung and Kember (2003), the reliability estimates range from .58 to .74 for the four subscales of the RTQ. The items are answered on a seven-point scale from 1 ("definitely agree") to 7 ("definitely disagree"); for example, "When I am working on some activities, I can do them without thinking about what I am doing." (habitual action), "I need to understand the material taught by the teacher in order to perform practical tasks." (understanding), "I sometimes question the way others do something and try to think of a better way." (reflection), and "As a result of this course I have changed my normal way of doing things." (critical reflection).

\section{Procedure}

The study was conducted in three universities in Mashhad between October and December 2014. 215 questionnaires were distributed out of which 196 were returned. 
The participation in research was completely voluntary. They were also asked to indicate their grade point average (GPA) as an indication of academic achievement as well as their demographic information on the questionnaires.

\section{FINDINGS}

The first phase of the present study included a series of different steps to validate the Persian version of the reflective thinking scale. Having translated the scales into Persian, a group of experts (two psychometricians, and three English educators) evaluated the quality of items in terms of clarity and comprehensiveness. Accommodating the experts' views resulted in more refined and comprehensible version of the scale. The translated version was then back translated to add additional quality check to the initial translated version and to verify the accuracy of the translation. The translated questionnaire was then administered to the sample of the study.

To determine the validity of the translated questionnaire in Iranian context, a confirmatory factor analysis (CFA) utilizing the LISREL 8.50 statistical package was performed. The model consisted of four factors: habitual action, understanding, reflection, and critical reflection. Each factor contained four items. A number of fit indices were examined to evaluate the model fit: the chi square/ $d f$ ratio which should be lower than 2 or 3, the normed fit index (NFI), the good fit index (GFI), and the comparative fit index (CFI) with the cut value greater than .90, and the root mean square error of approximation (RMSEA) of about .06 or .08 (Schreiber, Amaury, Stage, Barlow, \& King, 2006). The structural model is presented in Figure1. As indicated by Figure 1, the chi-square/df ratio (2.66), the RMSEA (.068), GFI (.89), GFI (.90), and CFI (.90) all reached the acceptable fit thresholds.

The indices on the lines indicate the standardized estimates and $t$-values, respectively. The first one is the standardized coefficient $(\beta)$ which demonstrates the factor loading of each item with respect to the corresponding factor and presents an easily grasped picture of effect size. The closer the magnitude to 1.0, the higher the correlation and the greater the factor loading of the item is. The magnitude of lower than 0.30 is an indication of weak factor loading; in such cases the item must be revised or discarded. The second measure is the $t$-value ( $\mathrm{t}$ ); if $t>2$ or $t<-2$, we call the result statistically significant. As the figure demonstrates, all items had accepted factor loadings enjoying $t$-values higher than 2 and $\beta$ indices greater than 0.30 . 


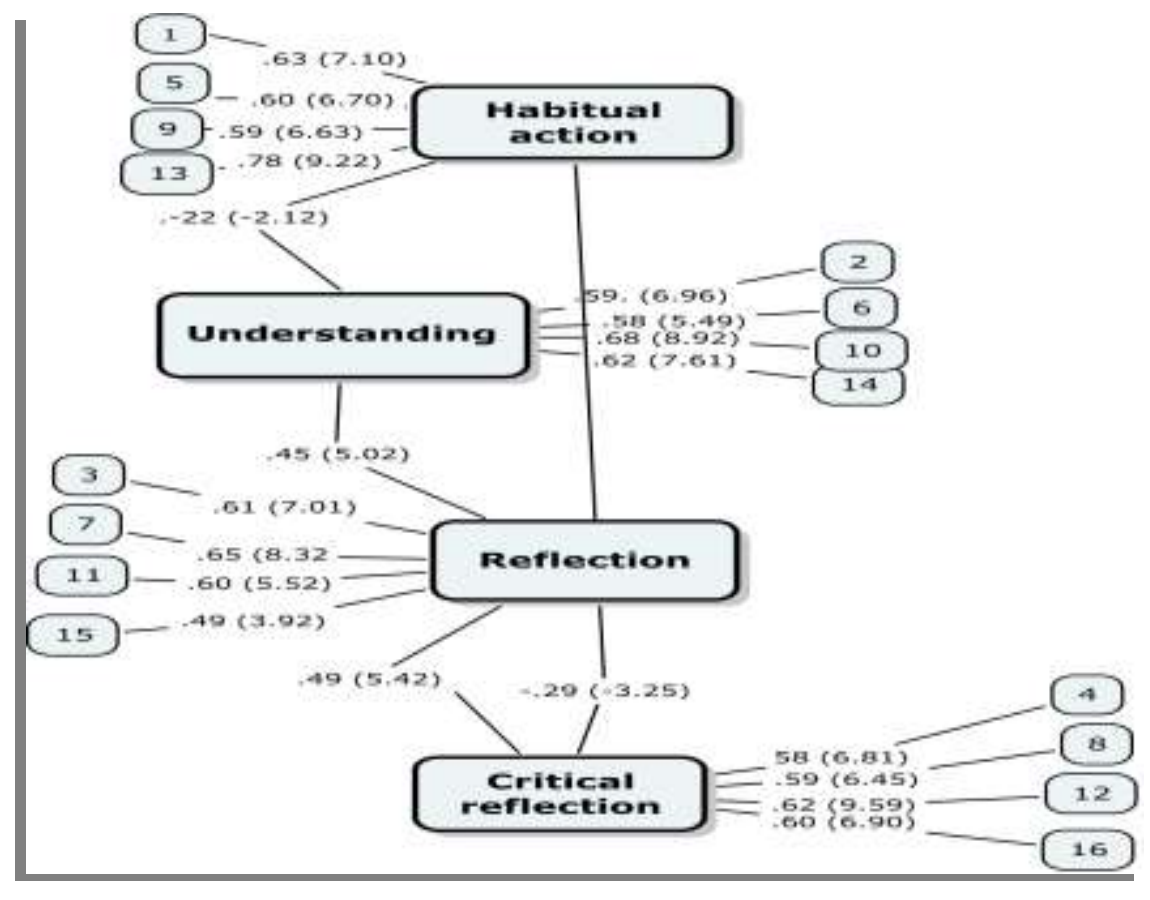

$\chi 2=322.21, d f=121, R M S E A=.068, G F I=.89, N F I=.90, C F I=.90$

Figure 1

The schematic representation of reflective thinking and its comprising factors

The convergent validity of the four-factor model was then model computed via correlation between factors. Table 1 below represents the results.

Table 1

The Correlation Coefficients among Reflective Thinking Components (Habitual action, Understanding, Reflection, Critical Reflection) and GPA

\begin{tabular}{lllll}
\hline & $H A$ & $U N D$ & $R E F$ & $C R E F$ \\
\hline 1. HA & 1.00 & & & \\
\hline 2. UND & $-.62^{* *}$ & 1.00 & & \\
\hline 3. REF & $-.57^{* *}$ & $.84^{* *}$ & 1.00 & \\
\hline 4. CREF & $-.60^{* *}$ & $.78^{* *}$ & $.70^{* *}$ & 1.00 \\
\hline
\end{tabular}

***orrelation is significant at the level of 0.05

As the Table indicates, the model with the best fit demonstrated inter-correlation between the scales or latent factors with REF and UND having the highest correlation $(r=.84, p<0.05)$ and HA having negative associations with other components. This is in accordance with the validity indices of the original scale as reported by Kember et al (2000). As contended by Kember et al (2000), this finding is predicted conceptually given that those involved in critical refection are also likely to have reflected upon their 
practice. Students who engage in either form of reflection may also have a tendency to study for understanding, particularly in more theoretical parts of a course, which have less obvious relationships to practice. The negative correlation between critical reflection and habitual action may be explained in the light of the conceptualization of habitual action which has a more mechanical and perfunctory nature. The other three components, nevertheless, require conscious attention, evaluation, and deep comprehension.

The reliability of the questionnaire estimated via Cronbach's alpha was found to be .81 . The reliability of each subscale was as follows: habitual action (.78), understanding (.84), reflection (.80), and critical reflection (.74). Overall, it can be concluded that the Persian version of reflective thinking questionnaire had acceptable reliability and validity indices.

Table 2 presents descriptive statistics of EFL learners' reflective thinking comprising four components. As the Table shows, among the comprising factors of reflective thinking, understanding $(M=13.95, S D=3.47)$ has the highest mean followed by reflection $(M=13.30, S D=3.26)$. Habitual action $(M=10.17, S D=2.64)$ receives the lowest mean score.

Table 2

Descriptive Statistics of the Comprising Factors of Reflective Thinking

\begin{tabular}{lcccl}
\hline & Min & Max & Mean & SD \\
\hline Habitual Action & 5.00 & 16.00 & 10.17 & 2.64 \\
\hline Understanding & 5.00 & 20.00 & 13.95 & 3.47 \\
\hline Reflection & 6.00 & 20.00 & 13.30 & 3.26 \\
\hline Critical Reflection & 5.00 & 20.00 & 12.55 & 2.79 \\
\hline Valid N (listwise) & 196 & & & \\
\hline
\end{tabular}

To see whether these observed differences among the four components of reflective thinking are statistically significant, a one-way ANOVA was applied to the data. The test also serves as the discriminative evidence of the scale.

Table 3

The Results of One-Way ANOVA for Determining Differences among the Components of Reflective Thinking

\begin{tabular}{llllll}
\hline & Sum of Squares & $d f$ & Mean Square & $F$ & Sig. \\
\hline Between Groups & 1275.54 & 3 & 425.18 & 45.29 & .000 \\
\hline Within Groups & 5820.44 & 620 & 9.38 & & \\
\hline Total & 7095.98 & 623 & & & \\
\hline
\end{tabular}

As Table 2 indicates, there are significant differences among the four subscales of reflective thinking $(F=45.291, p<0.05)$.

The ANOVA analysis revealed that among the four components of reflective thinking, there is a difference somewhere among the means, but the precise location of differences is not clear. To locate the exact place of differences, a post-hoc comparison of the 
means was run for the five dimensions. In so doing, a Scheffe's test was utilized. Table 4 displays the results of Scheffe's test.

Table 4

The Scheffe's Test for Determining the Location of Difference across the Four Reflective Thinking

\begin{tabular}{|c|c|c|c|c|c|c|}
\hline & $(J)$ & Mean & Std. & Sig. & \multicolumn{2}{|c|}{$95 \%$ Confidence Interval } \\
\hline \multirow[t]{2}{*}{ VAR00002 } & VAR00002 & Difference (I- & Error & & Lower & Upper \\
\hline & & $J)$ & & & Bound & Bound \\
\hline & UND & $-3.78^{*}$ & .34 & .00 & -4.75 & -2.80 \\
\hline \multirow[t]{3}{*}{ HA } & REF & $-3.12^{*}$ & .34 & .00 & -4.10 & -2.15 \\
\hline & CREF & $-2.37^{*}$ & .34 & .00 & -3.35 & -1.40 \\
\hline & HA & $3.78^{*}$ & .34 & .00 & 2.80 & 4.75 \\
\hline \multirow[t]{3}{*}{ UND } & REF & .65 & .34 & .31 & -.31 & 1.62 \\
\hline & CREF & $1.40^{*}$ & .34 & .00 & .43 & 2.37 \\
\hline & HA & $3.12^{*}$ & .34 & .00 & 2.15 & 4.10 \\
\hline \multirow[t]{3}{*}{ REF } & UND & -.65 & .34 & .31 & -1.62 & .318 \\
\hline & CREF & .75 & .34 & .19 & -.22 & 1.72 \\
\hline & HA & $2.37^{*}$ & .34 & .00 & 1.40 & 3.35 \\
\hline \multirow[t]{2}{*}{ CREF } & UND & $-1.40^{*}$ & .34 & .00 & -2.37 & -.43 \\
\hline & REF & -.750 & .346 & .198 & -1.72 & .22 \\
\hline
\end{tabular}

*. The mean difference is significant at the 0.05 level.

The results of the post hoc Scheffe's test revealed that, at the level of 0.05 there was a significant difference between HA, UND, REF, and CREF. The mean scores of UND is significantly different from those of HA and CREF but not from that of REF. The mean scores of REF is significantly different from that of HA but not from mean scores of UND and CREF. The mean scores of CREF is significantly different from HA and UND but not from that of REF.

To examine the relationship between reflective thinking and academic achievement (GPA), a Pearson product-moment correlation was run. Descriptive statistics of students' GPA are as follows: minimum $=13.50$, maximum $=18.25$, mean $=16.34$, and $S D=1.20$. The correlation coefficients among EFL learners' reflective thinking and academic achievement (GPA) are presented in Table 5. As it can be seen, the highest correlation is observed between UND and GPA $(r=0.566, p<0.05)$. The second higher correlation was found between REF and GPA $(r=0.477, p<0.05)$, followed by CREF and GPA $(r$ $=0.477, p<0.05)$. It was also found that there is a negative significant correlation between HA and GPA $(r=-0.327, p<0.05)$.

Table 5

The Correlation Coefficients between Reflective Thinking (Habitual action, Understanding, Reflection, Critical Reflection) and GPA

\begin{tabular}{lllll}
\hline & $H A$ & $U N D$ & $R E F$ & $C R E F$ \\
\hline GPA & $-.32^{* *}$ & $.56^{* *}$ & $.47^{* *}$ & $.44^{* *}$ \\
\hline
\end{tabular}

***orrelation is significant at the level of 0.05 
To delve more into EFL learners' reflective thinking, the association of each thinking style with learners' demographic variables such as, gender and educational level was estimated.

The following Table shows the descriptive statistics of thinking styles across two educational levels: 1) BA and 2) MA.

Table 6

Descriptive Statistics of Reflective Thinking across BA and MA University Students

\begin{tabular}{lccccc}
\hline & Level & $N$ & Mean & Std. Deviation & Std. Error Mean \\
\hline \multirow{2}{*}{ HA } & 1.00 & 101 & 11.59 & 2.44 & .28 \\
& 2.00 & 95 & 8.98 & 2.19 & .23 \\
\multirow{2}{*}{ UND } & 1.00 & 101 & 11.09 & 2.51 & .29 \\
& 2.00 & 95 & 16.34 & 2.09 & .22 \\
\hline \multirow{2}{*}{ REF } & 1.00 & 101 & 10.61 & 2.20 & .26 \\
& 2.00 & 95 & 15.54 & 2.11 & .22 \\
\hline \multirow{2}{*}{ CREF } & 1.00 & 101 & 10.64 & 2.23 & .23 \\
& 2.00 & 95 & 14.14 & 2.14 & .23 \\
\hline
\end{tabular}

As the Table indicates, BA students obtained higher mean scores in HA but lower mean scores in the other three thinking styles in comparison with their MA counterparts. To see if these observed differences are significant statistically, a one-way between-groups multivariate analysis of variance (MANOVA) was run to examine the differences in reflective thinking in relation to the educational level. Four dependent variables were generated: habitual action, understanding, reflection, and critical reflection. The independent variable was educational level. Preliminary assumption testing was conducted to check for normality, linearity, univariate and multivariate outliers, homogeneity of variance covariance matrices, and multicollinearity, with no serious violations noted. The results of MANOVA presented in Table 7 revealed that was a statistically significant difference between BA and MA students on the combined dependent variables (reflective thinking): $\quad(F=52.80,473, p=.000$, Wilks' Lambda $=1.39$ ). The effect size computed via partial eta squared was found to be .58 which is a quite high magnitude according to Cohen's F. This implies that about 58 percent of variance in reflective thinking can be accounted by educational level.

Table 7

MANOVA Table Displaying the Results of Level Differences in Reflective Thinking

\begin{tabular}{lccccccc}
\hline Effect & Value & $F$ & $\begin{array}{c}\text { Hypothesis } \\
d f\end{array}$ & $\begin{array}{c}\text { Error } \\
d f\end{array}$ & $\begin{array}{c}\text { Sig. } \\
\text { Partial Eta } \\
\text { Squared }\end{array}$ \\
\hline Level & Wilks' Lambda & 1.39 & 52.8 & 4.00 & 151.00 & .00 & .58 \\
\hline
\end{tabular}

The follow-up analysis represented in Table 8 demonstrated that this difference holds true across all four components of reflective thinking: HA $(F=49.23, p=.000$, partial eta squared $=.24)$, UND $(F=201.80, p=.000$, partial eta squared $=.56)$, CREF $(F=201.01$, $p=.000$, partial eta squared $=.56), \operatorname{CREF}(F=98.71, p=.000$, partial eta squared $=.39)$. As it can be seen, the highest difference in observed in UND followed by REF in favor of MA students. The lowest difference is obtained in HA in favor of BA students as the inspection of mean scores indicated. 
Table 8

MANOVA Table Displaying the Results of Level Differences in the Components of Reflective Thinking

\begin{tabular}{llcccccc}
\hline Source & $\begin{array}{l}\text { Dependent } \\
\text { Variable }\end{array}$ & $\begin{array}{c}\text { Type III } \\
\text { Sum of } \\
\text { Squares }\end{array}$ & $d f$ & $\begin{array}{c}\text { Mean } \\
\text { Square }\end{array}$ & $F$ & Sig. & $\begin{array}{c}\text { Partial Eta } \\
\text { Squared }\end{array}$ \\
\hline \multirow{3}{*}{ Level } & HA & 262.18 & 1 & 262.18 & 49.23 & .00 & .24 \\
\cline { 2 - 9 } & UND & 1063.27 & 1 & 1063.27 & 201.80 & .00 & .56 \\
\cline { 2 - 8 } & REF & 937.00 & 1 & 937.00 & 201.01 & .00 & .56 \\
\cline { 2 - 9 } & CREF & 472.08 & 1 & 472.08 & 98.71 & .00 & .39 \\
\hline
\end{tabular}

Identical analysis was conducted for the role of gender in each thinking style. Table 9 presents the descriptive statistics of thinking styles across genders: 1) female and 2) male.

Table 9

Descriptive Statistics of Reflective Thinking across Male and Female University Students

\begin{tabular}{llcccc}
\hline & Gender & $N$ & Mean & Std. Deviation & Std. Error Mean \\
\hline \multirow{2}{*}{ HA } & 1.00 & 112 & 10.19 & 2.41 & .23 \\
& 2.00 & 75 & 10.12 & 3.04 & .41 \\
UND & 1.00 & 112 & 13.94 & 3.48 & .34 \\
& 2.00 & 75 & 13.98 & 3.50 & .47 \\
REF & 1.00 & 112 & 13.21 & 3.26 & .32 \\
& 2.00 & 75 & 13.46 & 3.29 & .44 \\
CREF & 1.00 & 112 & 12.48 & 2.74 & .27 \\
& 2.00 & 75 & 12.68 & 2.89 & .39
\end{tabular}

$\mathrm{T}$ As the Table indicates, male and female students' scores on reflective thinking are quite close to each other. A MANOVA was performed to see if these slight differences are statistically different. Four dependent variables were generated: habitual action, understanding, reflection, and critical reflection. The independent variable was gender. Preliminary assumption testing was conducted to check for normality, linearity, univariate and multivariate outliers, homogeneity of variance covariance matrices, and multicollinearity, with no serious violations noted. The results of MANOVA presented in Table 10 revealed that was not a statistically significant difference between males and females on the combined dependent variables (reflective thinking): ( $F=0.47, p=.75$, Wilks' Lambda= .98).

Table 10

MANOVA Table Displaying the Results of Gender Differences in Reflective Thinking

\begin{tabular}{|c|c|c|c|c|c|c|c|}
\hline Effect & & Value & $F$ & $\begin{array}{c}\text { Hypothesis } \\
d f\end{array}$ & $\begin{array}{c}\text { Error } \\
D f\end{array}$ & Sig. & $\begin{array}{l}\text { Partial Eta } \\
\text { Squared }\end{array}$ \\
\hline Gender & Wilks' Lambda & .98 & .47 & 4.00 & 151.0 & .75 & .01 \\
\hline
\end{tabular}




\section{DISCUSSION}

The present study aimed at exploring the effects of four components of reflective thinking namely; understanding, reflection, critical reflection, and habitual action on university students' academic achievement. It also delved into the role of student demographic variables (educational level and gender) in student reflective thinking. To attain the goals of present research, the Persian version of reflective thinking questionnaire was administered to a sample of Iranian university students. The results of CFA and reliability estimates substantiated the validity and reliability of the scale.

As the results demonstrated, understanding received the highest mean followed by reflection and critical reflection. Habitual action, on the other hand, had the lowest mean score. In other words, the ability to analyze and critique information at a high-order level, i.e., understanding, reflection, and critical reflection, is demonstrated among higher education students more frequently than abilities associated with lower-order thinking such as memorization and rote-learning, i.e., habitual action. In effect, reflection and critical reflection components constitute deep learning approaches by which higher education learners can overcome uncertainties and fears to have a critical evaluation of their practices and make meaningful changes. Such differences are due to the particular characteristics of higher education students. In particular, university students are expected to build a deep understanding of the core concepts of course materials, prevent mechanical and habitual learning, try to be intrinsically motivated, autonomous, be responsible for their own learning and progress to enhance problem solving strategies, reflect on their accomplishments, and evaluate or self-monitor their work (Boyd \& Fales, 1983; Mezirow, 1997; Monshi Tousi \& Ghanizadeh, 2012). Consequently, higher education students should gain profound insights which cannot be manifested in habitual actions.

The above finding corroborates the contention that development through enhanced reflective thinking occurs most frequently during higher education (Kitchener \& King, 1981, as cited in Sargent, 2015). It is also in concert with Sargent's (2015) study among college students. It was revealed that habitual thinking had lowest score whereas understanding score was the highest. Also, it was reported that nearly all students believed that college required them to understand and reflect. The findings of the current research also demonstrated the highest correlations between understanding and academic achievement followed by reflection and critical reflection, respectively. Habitual action, on the other hand, was found to have a negative relationship with student academic achievement. There is a general consensus among educationalists that developing higherorder thinking skills of university students must constitute an indispensable part of the agenda of higher education. Scholars in the field of higher education contended that reflective thinking is a standard of intellectual excellence required for full and constructive participation in academic, individual, and social lives of students (Scriven $\&$ Paul, 2004).

This finding corroborates previous studies in which the use of higher-order learning strategies often leads to improvements in student proficiency and achievement (Watkins, 
Regmi, \& Astilla, 1991; Thompson \& Rubin, 1993; Drew \& Watkins, 1998; EklundMyrskog \& Wenestam, 1999; Watkins, 2001; Lucas, 2012). Moreover, strategic learners adapt metacognitive knowledge for their learning approaches and a comprehensive understanding of what a task entails (Chamot, 2004). Key to this discussion, educational scholars considered reflection a form of freedom from routine behavior which emancipates us from merely impulsive and routine activity; it enables people to direct their activities with foresight and to plan according to ends-in-view or purposes of which they are aware, to act in deliberate and intentional fashion, to know what they are about when they act (Farrell, 2014).

The next finding of the present study revealed that graduate higher education students (students studying in MA or having a MA degree in this study) employed deep thinking styles, i.e., understanding, reflection, and critical reflective thinking more frequently than their BA counterparts. The fluctuations regarding the use of reflective thinking strategies can be justified by the variation of learners' attitudes of academic achievement as their transition from BA to MA level. Such an alternation can be followed by changes in students' efficacy beliefs, motivation levels, and goal settings (Phan, 2009). Since higher education learners at MA levels are empowered by social and environmental factors and are expected to write a thesis before graduating from the program, they experience more challenges than BA counterparts. Consequently, they are expected to be involved in reasoning, hypothesizing, problem solving, and assessing, all of which are manifestation of reflective thinking. Overall, this attested to Fischer and Pruyne's (2003) belief that student variables regulate the direction and area in which thinking develops (as cited in Sargent, 2015).

The last finding of this research concerned gender differences in reflective thinking. No differences were observed across the four comprising factors of reflective thinking. That is, both male and female university students are virtually involved in learning strategies and higher order thinking skills to facilitate the learning process. The finding is in line with previous studies finding no statistical difference between males and females regarding their use of reflective thinking strategies (King \& Kitchener, 1994; Phan, 2009). It, nevertheless, contradicts a recent study by Sargent (2015) who detected gender differences in undergraduates' reflective thinking across three disciplines. In particular, it was reported that males reported more reflection in business courses than the humanities or science courses, while females displayed more reflection in humanities and science courses and less in business courses.

\section{CONCLUSION AND IMPLICATION}

Taken together, the findings of the present study shed light on the crucial role of reflective thinking components in students' academic achievement. It also put forward important implications for both higher education instructors and students. Higher education instructors should underscore the belief that teaching for thinking skills is an important goal of modern education, given that it provides students with the abilities necessary to reason about social affairs in a rapidly changing world (Ku, 2009). Hence, reflective practice on the part of the teachers enables them to act in a critical manner, stimulate deep understanding, trigger positive change, and raise their awareness 
regarding the act of teaching (Farrell, 2014). Second, instructors' involvement in reflective teaching improves students' ability to investigate reflective thinking strategies (Yost, Sentner, \& Frolenza-Baily, 2000).

\section{REFERENCES}

Alger, C. (2006). What went well, what didn't go so well: Growth of reflection in preservice teachers. Reflective Practice, 7(3), 287-301.

Barton, G., \& Ryan, M. (2014). Multimodal approaches to reflective teaching and assessment in higher education. Higher Education Research \& Development, 33 (3), 409-424. DOI: 10.1080/07294360.2013.841650

Bloom, B. S. (1979). Taxonomy of Educational Objectives, Book I: Cognitive domain, London: Longman.

Boyd, E. M., \& Fales, A. W. (1983). Reflective learning. Journal of Humanistic Psychology, 23(2), 99-117.

Chamot, A. (2004). Issues in Language Learning Strategy Research and Teaching. Electronic Journal of Foreign Language Teaching, 1(1), 14-26.

Dawe, G., Jucker, R., \& Martin, S. (2005). Sustainable Development in Higher Education: Current Practice And Future Developments. A report for the Higher Education Academy. www.heacademy.ac.uk/assets/York/documents/ ourwork/tla/ sustainability.

Dewey, J. (1933). How We Think. Chicago: Henry Regnery.

Drew, P., \& Watkins, D. (1998). Affective variables, learning approaches and academic achievement: A causal modeling investigation with Hong Kong tertiary students. British Journal of Educational Psychology, 68, 173-188.

Eklund-Myrskog, G., \& Wenestam, C. G. (1999). Students approaches to learning in Finnish general upper secondary school. Scandinavian Journal of Educational Psychology, 43, 5-18.

Farrell, T. (2014). Reflective Practice in ESL Teacher Development Groups: From Practices to principles. London: MacMillan.

Fischer, K.W., \& Pruyne, E. (2003). Reflective thinking in adulthood. In J. Demick \& C. Andreoletti (Eds.), Handbook of Adult Development (pp. 169-198). New York: Kluwer Academic/Plenum.

Ghanizadeh, A. (2016). The interplay between reflective thinking, critical thinking, selfmonitoring, and academic achievement in higher education. Higher Education. doi: 10.1007/s10734-016-0031-y

Huitt, W. (1998). Critical Thinking: An Overview. Valdosta, GA: Valdosta State University. 
Kalk, K., Luik, P., Taimalu, M., \& Täht, K. (2014). Validity and reliability of two instruments to measure reflection: A confirmatory study. Trames: A Journal of the Humanities and Social Sciences, 18(2), 121-134.

Kember, D., Leung, D., Jones, W., \& Loke, A. (2000) Development of a questionnaire to measure the level of reflective thinking. Assessment \& Evaluation in Higher Education, 25 (4), 381-395.

Killeavy, M., \& Moloney, A. (2010). Reflection in a social space: Can blogging support reflective practice for beginning teachers? Teaching and Teacher Education, 26, 10701076.

King, P., \& Kitchener, K. (1994). Developing Reflective Judgment. San Francisco: Jossey-Bass.

Krebel, C. (2005). Reflection on teaching and the scholarship of teaching: Focus on science instructors. Higher Education, 50, 323-359.

$\mathrm{Ku}$, K. Y. L. (2009). Assessing students' critical thinking performance: Urging for measurements using multi-response format. Thinking Skills and Creativity, 4, 70-76.

Lim-Ng, Y. P. D. (2009). Assessing Secondary Students' Reflective Thinking in Project Work. Paper presented at the 35th Annual Conference of the International Association for Educational Assessment (IAEA), Brisbane.

Lucas, P. (2012). Critical reflection. What do we really mean? Australian Collaborative Education Network (ACEN Inc). Retrieved March 2014 from: http://acen.edu. $\mathrm{au} / 2012$ conference/wp content/uploads/2012/11/92_Critical-reflection.pdf.

Lucas, U., \& Leng Tan, P. (2006). Assessing levels of reflective thinking: The evaluation of an instrument for use within accounting and business education. Paper presented to the 1st Pedagogic Research in Higher Education Conference, Liverpool Hope University: Liverpool, 2nd/3rd May.

Maaranen, K., \& Leena K. (2007) Time to think? Primary school teacher students reflecting on their MA thesis research processes. Reflective Practice 8, 3, 359-373.

Mezirow, J. (1991). Transformative Dimensions of Adult Learning. Sanfrancisco, CA: Jossey-Bass.

Mezirow, J. (1977). Perspective transformation. Studies in Adult Education, 9(2), 153164.

Monshi Toussi, M. T., \& Ghanizadeh, A. (2012). A study of EFL teachers' locus of control and self-regulation and the moderating role of self-efficacy. Theory and Practice in Language Studies, 2(11), 2363-2371.

Moore, T.J. (2011). Critical thinking and disciplinary thinking: a continuing debate. Higher Education Research \& Development, 30 (3), 261-274. DOI: 10.1080/07294360.2010.501328 
Ottesen, E. (2007). Reflection in teacher education. Reflective Practice, 8(1), 31-46.

Sargent, C, S. (2015). Evidence of reflective thinking across the curriculum: college experience versus individual courses. Higher Education Research \& Development, 34 (3), 624-640. DOI: 10.1080/07294360.2014.973375

Shoffner, M. (2009). The place of personal: Exploring the affective domain through reflection in teacher preparation. Teaching and Teacher Education, 25, 783-789.

Shokouhi, M., Moghimi, A., \& Hosseinzadeh, S. (2015). Introducing reflective practice from a sociocultural perspective: Toward a strategically mediated reflective practice framework. Journal of Applied Linguistics and Language Research, 2(4), 74-83.

Smith, V.G., \& Szymanski, A. (2013). Critical thinking: More than test scores. International Journal of Educational Leadership Preparation, 8 (2), 15-24.

Sobral, D. (2001). Medical students' reflection in learning in relation to approaches to study and academic achievement. Medical Teacher,23(5), 508-513.

Tigelaar, D., Dolmans, D., De Grave, W., Wolfhagen, I., \& Van der Vleuten, C. (2006). Portfolio as a tool to stimulate teachers' reflections. Medical Teacher 28(3), 277-282.

Watkins, D. (2001). Correlates of approaches to learning: A cross-cultural mataanalysis. In R. Sternberg \& L. F Zhang (Eds.), Perspectives on thinking, learning, and cognitive styles, (pp. 165-195). Mahwah, NJ: Lawrence Erlbaum.

Watkins, D., Regmi, M., \& Astilla, E. (1991). The Asian learner as a rote learner stereotype: Myth or reality. Educational Psychology, 11, 21-34.

Yost, D., Sentner, S., \& Frolenza-Baily, A. (2000). An examination of the construct of critical reflection: Implications for teacher education programming in the 21st century. Journal of Education, 51(1), 31-65. 


\section{Turkish Abstract \\ Yansıtıcı Düșünme Anketinin Farsça Versiyonunun Doğrulanması ve İran Üniversite Öğrencilerinin Yansıtıcı Düşünce ve Akademik Başarılarının İncelenmesi}

Yükseköğretimdeki araştırmacılar, mesleki disiplin uygulamalarının geliştirilmesinde yansıtıcı düşünmenin ayrılmaz bir parça olduğuna inanmaktadırlar. Yansitıcı düşünmenin araştırılmasındaki en önemli konulardan biri yansıtıcı düşünmenin kavramsallaştırılması ve değerlendirilmesi etrafında şekillenmektedir. Yıllar boyunca araştırmacılar, yansıtıcı düşünmeyi ölçmek için çeşitli yöntemler ve ölçekler kullanmışlardır. En yaygın olarak bilinen düşünsel ölçeklerden biri Kember ve diğerleri tarafindan geliștirilmiş ve onaylanmıștır. (2000). B ölçek "Reflektif Düşünme Anketi (RTQ)" başlıklı ve dört tür yansıtıcı düşünceyi ölçen 16 madde içermektedir: Anlama (UND); Yansıtma (REF); Eleştirel yansıma (CREF); Alışılmış eylem (HA). $\mathrm{Bu}$ çalışma, yüz doksan altı İngilizce yabancı dil (EFL) üniversite öğrencisi arasında RTQ'nun Farsça versiyonunun geçerliliğini sağlamayı amaçlamaktadır.

Anahtar Kelimeler: EFL öğrencileri, yansıtıcı düşünme, dil öğrenme başarısı (GPA), anlama (UND), yansıtma (REF), eleștirel yansıtma (CREF), alıșılmıș eylem (HA)

\section{French Abstract}

Valider la Version persane de Questionnaire Pensant Réfléchissant et des Investigations de la Pensée Réfléchissante des Étudiants Universitaires iraniens et l'Accomplissement Universitaire

Les érudits dans l'enseignement supérieur considèrent la pensée réfléchissante comme intégral au développement de pratiques disciplinaires professionnelles. Un des problèmes majeurs dans étude de pivots pensants réfléchissants autour de sa conceptualisation et évaluation. Au fil des ans, les chercheurs ont utilisé plusieurs méthodes et échelles pour mesurer la pensée réfléchissante. Une de des échelles le plus largement connue de pensée réfléchissante a été construite et validée par Kember et d'autres. (2000). Il a droit ' le Questionnaire Pensant Réfléchissant(Réfléchi) (RTQ) ' et inclut 16 articles mesurant quatre types de pensée réfléchissante: compréhension (UND); réflexion(reflet) (RÉF); réflexion(reflet) critique (CREF); action habituelle (HA). L'étude présente a visé à valider la version persane de RTQ parmi cent quatre-vingt-seize anglais langue étrangère (EFL) des étudiants universitaires.

Mots Clés: EFL apprenants, pensée réfléchissante, accomplissement de langue (GPA) compréhension (UND), réflexion(reflet) (RÉF), réflexion(reflet) critique (CREF), action habituelle (HA) 


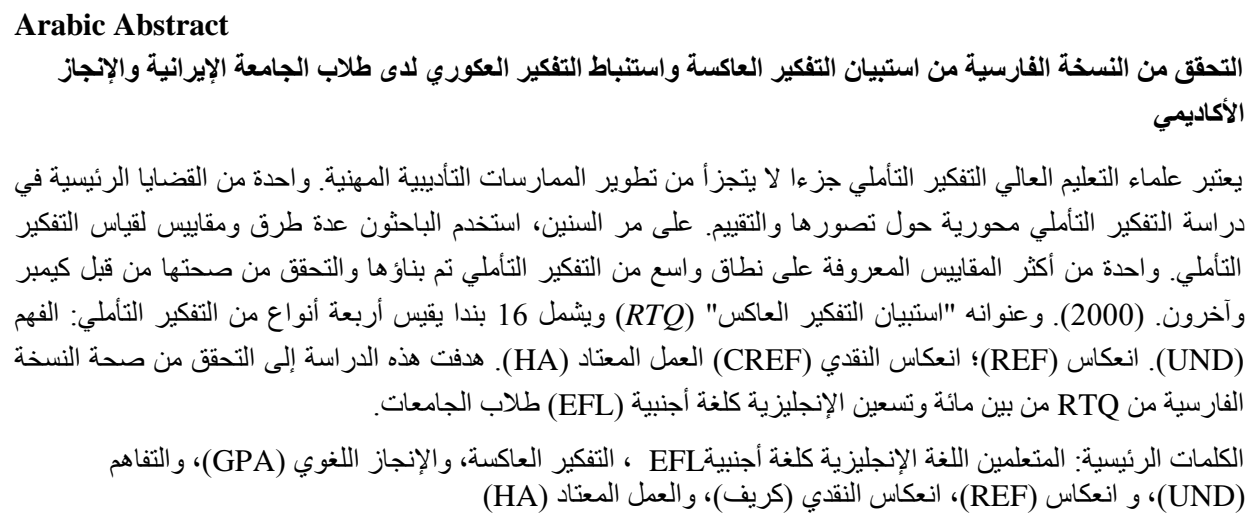

German Abstract

Validierung der persischen Version des reflektierenden Denken Fragebogens und Probing Reflective Thinking und akademische Leistung der iranischen Universitätsstudenten

Gelehrte in der Hochschulbildung sehen das reflektierende Denken als integraler Bestandteil der Entwicklung von professionellen Disziplinarpraktiken an. Eines der Hauptprobleme beim Studium des reflektierenden Denkens ist die Konzeption und Bewertung. Im Laufe der Jahre haben die Forscher mehrere Methoden und Skalen verwendet, um das reflektierende Denken zu messen. Eine der bekanntesten Skalen des reflektierenden Denkens wurde von Kember et al. Konstruiert und validiert. (2000). Es handelt sich um einen "Reflektierenden Denken Fragebogen (RDF)" und umfasst 16 Punkte, die vier Arten von reflektierendem Denken messen: Verständnis (UND); Reflexion (REF); Kritische Reflexion (KREF); Gewohnheitsaktion (GA). Die vorliegende Studie zielte darauf ab, die persische Version von RDF unter einhundertsechsundneunzig Englisch als Fremdsprache (EAZ) Universitätsstudenten zu validieren.

Schlüsselwörter: EAZ-Lernende, reflektierendes Denken, Spracherfolg (SE), Verständnis (UND), Reflexion (REF), kritische Reflexion (KREF), Gewohnheitsaktion (GA) 


\begin{abstract}
Malaysian Abstract
Mengesahkan Versi Parsi Pemikiran Mencerminkan Refleksi dan Pengajaran Pemikiran Reflektif dan Pencapaian Akademik Pelajar Universiti Iran

Ulama dalam pendidikan tinggi menyatakan pemikiran reflektif sebagai penting kepada pembangunan amalan disiplin profesional. Salah satu isu utama dalam mengkaji pivots pemikiran reflektif di sekitar konsep dan penilaiannya. Selama bertahun-tahun, penyelidik telah menggunakan beberapa kaedah dan skala untuk mengukur pemikiran reflektif. Salah satu daripada skala paling terkenal pemikiran reflektif telah dibina dan disahkan oleh Kember et al. (2000). Ia bertajuk 'Soal Selidik Pemikiran Reflektif (RTQ) dan termasuk 16 barangan berukuran empat jenis pemikiran reflektif: persefahaman (UND); pantulan (REF); refleksi (CREF); tindakan yang lazim (HA). Kajian ini bertujuan untuk mengesahkan versi Parsi RTQ antara 196 Bahasa Inggeris sebagai bahasa asing (EFL) pelajar universiti.
\end{abstract}

Kata Kunci: pelajar EFL, pemikiran reflektif, pencapaian bahasa (GPA), pemahaman (UND), refleksi (REF), refleksi kritikal (CREF), tindakan yang lazim (HA)

\title{
Russian Abstract \\ Валидация Персидской Версии Рефлексивного Мышления Анкета и Расследование Рефлексивного Мышления и Академических Достижений Учащихся Иранского Университета
}

Ученые с высшим образованием считают рефлексивное мышление необходимым для развития профессиональных дисциплинарных практик. Одна из основных проблем в изучении рефлективного мышления сводится к ее концептуализации и оценке. На протяжении многих лет исследователи использовали несколько методов и шкал для измерения рефлексивного мышления. Один из наиболее широко известных масштабов рефлексивного мышления был построен и подтвержден Кембером и др. (2000). Он озаглавлен как ‘Вопросник Рефлексивного Мышления (RTQ)' и включает в себя предметы четырех типов рефлексивного мышления: понимание (UND); Отражение (REF); Критическая рефлексия (CREF); Привычное действие (HA). Настоящее исследование было направлено на утверждение персидской версии RTQ среди ста девяноста шести человек, изучающих английский как иностранный язык.

Ключевые Слова: учащиеся EFL, рефлексивное мышление, языковые достижения (GPA), понимание (UND), рефлексия (REF), критическое отражение (CREF), привычное действие (HA) 